\title{
Chemotherapeutics for vivax malaria
}

\author{
J Kevin Baird \\ From Challenges in malaria research \\ Basel, Switzerland. 10-12 October 2012
}

Plasmodium vivax imposes significant burdens of morbidity and mortality across the malaria endemic world. Treatment of this infection requires a blood schizontocide against the acute attack and hypnozoitocide against relapses. Chloroquine combined with primaquine has been the therapy of choice for radical cure of vivax malaria since the 1950s. Primaquine, however, was never optimized or adapted for use in endemic zones and its toxicity in prevalent G6PD-defkient patients (typically 5-20\%) sharply limits its effectiveness. Resistance to chloroquine has emerged in Southeast Asia and now threatens the Indian sub-continent where most $P$. vivax occurs. The research community faces the steep challenge of developing new radical cure strategies. This presentation explores those challenges and the means to meet them, principally optimizing primaquine as a partner to new ACTs for maximum efficacy and more practical dosing and safety.

Published: 15 October 2012

Submit your next manuscript to BioMed Central and take full advantage of:

- Convenient online submission

- Thorough peer review

- No space constraints or color figure charges

- Immediate publication on acceptance

- Inclusion in PubMed, CAS, Scopus and Google Scholar

- Research which is freely available for redistribution (c) 2012 Baird; licensee BioMed Central Ltd. This is an Open Access article distributed under the terms of the Creative Commons Attribution License (http://creativecommons.org/licenses/by/2.0), which permits unrestricted use, distribution, and reproduction in any medium, provided the original work is properly cited. 